\title{
Evaluasi Teknik Penyuluhan Fasilitasi Balai Penyuluhan Pertanian Perikanan dan Kehutanan (Bp3k) dalam Penerapan Jajar Legowo di Kecamatan Teras Kabupaten Boyolali
}

\section{Extension Techniques Evaluationagricultural, Fisheries and Forestry Extension Center Fasilitation in Application Jajar Legowo at Teras District Boyolali Regency}

\author{
Dicky Alfrima Faqtoni, Bekti Wahyu Utami, Dwiningtyas Padmaningrum \\ Program Studi Penyuluhan dan Komunikasi Pertanian, Fakultas Pertanian \\ Universitas Sebelas Maret \\ Jl. Ir. Sutami No.36 A Kentingan Surakarta 57126 Telp/Fax (0271) 637457 \\ Email: dickyfaqtoni@gmail.com
}

\begin{abstract}
The Agricultual Extension, Fisheries and Forestry Center facilitation aims to support accelerated national strategic food production. One of intensification national food production intended to intensifiction rice production. The effort intensifiction rice production directed to applying jajar legowo plantation techniques. This study aims to examine the components of extension techniques effectiveness applying jajar legowo plantation by agricultural extension center in Teras District. This research used basic method is descriptive qualitative. Location determination of this research is purposive. The sampling technique used purposive sampling technique. The results of this research show that (1) The implementation of extension techniques in Teras district from the context aspect is good and adequate; (2) The implementation of extension techniques seen from the input aspect is good and adequate; (3)The implementation of extension techniques in seen from the process aspect is good; (4) The implementation of extension techniques from the product aspect is good and successful; (5) The effectiveness of extension techniques is good, it was proved by the increase of province and productivity
\end{abstract}

Keyword: CIPP, Evaluation, BP3K Facilitation,Jajar Legowo, ExtensionTechniques

\begin{abstract}
Abstrak: Fasilitasi Balai Penyuluhan Pertanian, Perikanan dan Kehutanan (BP3K) bertujuan mendukung tercapainya percepatan produksi pangan strategis nasional.Peningkatan produktivitas pangan nasional salah satunya dilakukan melalui penerapan teknologi tanam jajar legowo. Penelitian ini mengkaji komponen-komponen yang menentukan keefektifan teknik penyuluhan yang digunakan oleh BP3K di Kecamatan Teras dalam penerapan jajar legowo.Metode dasar penelitian yang digunakan adalah metode deskriptif kualitatif. Penentuan lokasi dilakukan secara purposive. Informan ditentukan dengan teknik purposive sampling. Hasil penelitian menunjukkan bahwa (1) pelaksanaan teknik penyuluhan BP3K di Kecamatan Teras dilihat dari aspek context tergolong baik dan memadai; (2) pelaksanaan teknik penyuluhan dilihat dari aspek input tergolong baik dan memadai; (3) pelaksanaan teknik penyuluhan dilihat dari aspek process tergolong baik; (4) pelaksanaan teknik penyuluhan dilihat dari aspek product tergolong baik dan berhasil; (5) keefektifan teknik penyuluhansudah baik, terbukti dengan terjadinya peningkatan provitas dan produktivitas hasil pertanian.
\end{abstract}

Kata Kunci: CIPP, Evaluasi, Fasilitasi BP3K, Jajar Legowo,Teknik Penyuluhan. 


\section{PENDAHULUAN}

Pembangunan pertanian berperan strategis dalam perekonomian nasional, yang ditunjukan oleh perannya dalam pembentukan kapital, penyediaan bahan pangan, bahan baku industri, pakan dan bioenergi, penyerap tenaga kerja, sumber devisa negara dan sumber pendapatan melalui praktek usahatani yang ramah lingkungan. Menurut Rivai (2011), pembangunan pertanian di Indonesia diarahkan menuju pembangunan pertanian berkelanjutan (sustainable agriculture), sebagai bagian dari implementasi pembangunan berkelanjutan (sustainable development). Menurut Undang-undang Nomor 16 tahun 2006, penyuluhan pertanian adalah proses pembelajaran bagi pelaku utama serta pelaku usaha agar mereka mau dan mampu mengorganisasikan dirinya dalam mengakses informasi pasar, teknologi, permodalan, dan sumber daya lainnya, sebagai upaya untuk meningkatkan produktivitas, efisiensi usaha, pendapatan dan kesejahteraannya dalam pelestarian fungsi lingkungan hidup.

Dalam pelaksanaan penyuluhan digunakan metode dan teknik penyuluhan yang disesuaikan agar dapat menjangkau sasaran. Van den Ban dan Hawkins (2003) mengungkapkan bahwa metode dan teknik penyuluhan yang digunakan oleh penyuluh sangat ditentukan oleh tujuan khusus yang akan dicapai. Keberhasilan dalam proses penyuluhan pertanian dikatakan tercapai ketika penentuan materi yang tepat dengan sasaran pembangunan pertanian tanpa mengabaikan kebutuhan dari petani. Pesan atau materi penyuluhan pertanian untuk dapat meningkatkan kemampuan, apabila cara penyampaian yang dipilih cocok dengan kondisi masyarakat petani. Memilih metode dan teknik ini menentukan keberhasilan di dalam penyelenggaraan program penyuluhan pertanian yang merupakan bagian dari pembangunan pertanian.

Peningkatan produktivitas pangan nasional salah satunya dimaksudkan untuk peningkatan produktivitas padi, yaitu usaha yang dilakukan untuk meningkatkan hasil pertanian dengan cara mengoptimalkan lahan pertanian yang sudah tersedia (existing). Dalam pelaksanaan intensifikasi pertanian akan fokus pada upaya penanganan masalah terkait: pengelolaan tanah, penggunaan benih bermutu, penanaman, pemupukan, pemberantasan hama serta penyakit pada tanaman, pemanenan dan kegiatan selama pasca panen (Kementrian Pertanian, 2016)

Dengan penerapan sistem tanam jajar legowo maka pada barisan tanaman terluar memberikan ruang tumbuh yang lebih longgar sekaligus sirkulasi udara dan pemanfaatan sinar matahari lebih baik untuk pertanaman. Selain itu upaya penanggulangan gulma dan pemupukan dapat dilakukan dengan lebih mudah. Kementrian Pertanian (2016), menyatakan pemahaman terhadap teknologi tanam jajar legowo padi menjadi penting agar manfaat yang akan diperoleh dari penerapannya akan lebih optimal. Sejalan dengan hal tersebut, maka pada tahun 2016 upaya peningkatan produksi padi akan diarahkan pada kegiatan peningkatan produktivitas (intensifikasi) melalui penerapan teknologi tanam jajar legowo. Untuk itu, kegiatan penyuluhan yang difasilitasi oleh Balai Penyuluhan Pertanian, Perikanan dan Kehutanan (BP3K) diarahkan guna mendukung terjadinya peningkatan produktivitas dengan penerapan sistem tanam jajar legowo.

Terdapat berbagai jenis teknik penyuluhan yang dipakai untuk meningkatkan kemampuan, pengetahuan, dan peningkatan produksi petani. Menarik untuk dikaji keefektifan teknik penyuluhan yang diterapkan dalam fasilitasiBalai Penyuluhan Pertanian, Perikanan dan Kehutanan (BP3K) di Kecamatan Teras mengingat prestasi yang ditorehkan oleh BP3K yaitu menjadi BP3K berprestasi tingkat regional dan nasional. Salah satu program peningkatan produksi yang dijalankan ialah penerapan sistem tanan jajar legowo. Melalui pendekatan evaluasi program dengan model CIPP (Context, Input, Process, Product) akan diperoleh gambaran mengenai komponen-komponen yang mendukung keberhasilan BP3K dalam penyelenggaraan fasilitasi penyuluhan bagi petani khususnya jajar legowo.

\section{METODE PENELITIAN}

Metode dasar penelitian yang digunakan adalah metode deskriptif kualitatif. metode deskriptif yaitu suatu penelitian yang memusatkan 
perhatian pada pemecahan masalah yang ada pada masa sekarang dan bertitik tolak dari data yang dikumpulkan dalam konteks teori-teori hasil penelitian terdahulu (Surakhmad, 2002). Pemilihan lokasi penelitian dilakukan dengan sengaja (purposive) yaitu di Kecamatan Teras Kabupaten Boyolali dengan pertimbangan bahwa Kabupaten Boyolali sebagai salah satu daerah yang memperoleh Fasilitasi BP3K dalam penerapan jajar legowo dan menjadi juara pertama sebagai BP3K berprestasi se-Jawa Tengah .

Informan ditentukan dengan teknik purposive sampling.Informan Kunci dari penelitian ini, adalah (1) Koordinator penyuluh BP3K Kecamatan Teras (2) Penyuluh pelaksana program penyuluhan (3) Ketua gapoktan yang terlibat dalam program (4) Petani yang mengikuti kegiatan penyuluhan yang difasilitasi oleh BP3K Kecamatan Teras

\section{HASIL DAN PEMBAHASAN}

\section{Pelaksanaan Teknik Penyuluhan Fasilitasi BP3K dalam Penerapan Sistem Tanam Jajar Legowo di Kecamatan Teras}

Kegiatan fasilitasi BP3K dalam penerapan jajar legowo dimulai dengan adanya rembug tani, yaitu kegiatan pertemuan rutin oleh petani atau kelompok tani dengan penyuluh yang bertujuan untuk merencanakan kegiatan usaha tani pada masa tanam berikutnya dan penyelesaian masalah yang dialami dan disepakati oleh peserta rembug tani. Setelah dilakukan rembug tani kemudian diteruskan dengan adanya praktik langsung atau kursus tani, yaitu kegiatan yang dilakukan petani sebagai pelaku utama dalam menerapkan suatu inovasi pertanian maupun penggunaan teknologi pertanian. Tujuan dari kursus tani adalah meningkatkan pengetahuan, kecakapan, sikap dan pengalaman petani. Farmer Field Day dilaksanakan sekali dan diikuti seluruh peserta di satu tempat yang telah ditentukan oleh penyuluh dan disepakati oleh poktan peserta.

Peserta kegiatan penyuluhan dalam Fasilitasi BP3K di Kecamatan Teras berkisar antara 20 - 40 peserta. Peserta kegiatan tersebut merupakan petani yang memiliki pengaruh di desadan lahan tempat mereka berusaha tani. Penyuluh melakukan controlling ke lahan petani yang digunakan untuk penerapan kegiatan penyuluhan khususnya jajar legowo yang sudah diajarkan, akan tetapi tidak semua desa di Kecamatan Teras mendapatkan pendampingan secara intensif. Mobilitas penyuluh yang terbatasi untuk menyiapkan acara World Food Day di Kabupaten Boyolali mengakibatkan penyuluh Kecamatan Teras tidak dapat mendampingi seluruh desa dengan intensifitas yang sama.

\section{Evaluasi Teknik Penyuluhan dalam Fasilitasi BP3K di Kecamatan Teras dengan Metode CIPP (Context, Input, Process, Product)}

\section{Aspek Context (Konteks)}

Dalam penelitian ini aspek konteks menilai kondisi sosial ekonomi dan kondisi geografis dan lingkungan.Berbagai komponen aspek konteks yang diteliti antara lain kondisi sosial ekonomi yang meliputi kondisi sosial ekonomi penyuluh dan kondisi sosial ekonomi petani, sertakondisi lingkungan geografis lahan pertanian di Kecamatan Teras.

\section{a. Kondisi Sosial Ekonomi}

Pendapatan petani peserta kegiatan penyuluhan yang difasilitasi $\mathrm{BP} 3 \mathrm{~K}$ mayoritas berada diatas RP. 2.000.000.00 per bulan. Tingkat pendapatan petani juga akan mempengaruhi petani dalam berusahatani, petani yang berpendapatan banyak cenderung lebih menerapkan inovasi baru yaitu jajar legowo.Petani peserta kegiatan penyuluhan yang difasilitasi BP3K selain sebagai petani yang mempunyai posisi penting di kelompok tani dan berpengaruh bagi petani lain. Petani peserta juga mempunyai lahan pertanian yang luas untuk usaha taninya. Luas lahan yang digunakan tersebut terdiri dari lahan kepemilikan sendiri, lahan menyewa dan lahan yang disakap oleh petani peserta.

Menurut Lionberger dalam Setiawan et all. (2006) menyatakan bahwa semakin luas lahan yang dikuasai petani biasanya petani cepat mengadopsi inovasi karena memiliki kemampuan ekonomi yang lebih baik. Komoditas yang ditanam di Kecamatan Teras ialah tanaman padi, jagung,palawija dan beberapa tanaman holtikultura. Varietas 
padi yang ditanam di kecamatan Teras diantaranya varietas situ bagendit, varietas IR 64, Mamberamo, pandanwangi dan beberapa padi dengan hasil pembibitan sendiri.

\section{b. Kondisi Lingkungan Geografis}

Ketersediaan air di Kecamatan Teras untuk kebutuhan produksi pertanian sudah mencukupi, penggunaan lahan di Kecamatan Teras menggunakan irigasi teknis, irigasi $1 / 2$ teknis, irigasi sederhana dan sedikit yang menggunakan tadah hujan. Dalam pengairan untuk irigasi ke areal lahan petani diatur oleh lembaga yaitu P3A, petani juga membuat sumur di dekat areal persawahan untuk berjaga-jaga apabila kekurangan air untuk kebutuhan usaha tani.

Organisme pengganggu tanaman yang terdapat di Kecamatan Teras ialah wereng, penggerek batang, belalang, ulat daun, lalat buah, ulat buah dan jamur/ cendawan, keong mas, tikus dan burung. Untuk penanganan hama tikus terdapat dua cara yaitu dengan musuh alami tikus yaitu burung hantu (tito alba) yang di pelihara di dekat areal sawah dan dengan penanganan serempak dengan gas sulfur/belerang yang di bakar di dekat lubang rumah tikus.

\section{Aspek Input (Masukan)}

Aspek Input merupakan usaha yang dilakukan baik fisik maupun non fisik yang menjadi dasar dan kelengkapan untuk terselenggaranya proses guna mencapai tujuan. Aspek masukan yang dinilai dari Fasilitasi BP3K ini meliputi sumber daya pelaksana, sumber pendukung, dan fasilitas penunjang.

a. Sumber Daya Pelaksana

Masukan mentah (raw input) ialah peserta didik yang bisa disebut juga dengan sumber daya pelaksana dan sasaran program (Sudjana, 2006). Dari hasil penelitian yang dilakukan umur peserta kegiatan penyuluhan yang difasilitasi BP3K di kecamatan Teras termasuk ke dalam kategori baik dikarenakan sebagian besar petani berumur produktif.Tingkat pendidikan petani peserta kebanyakan tamat SMA, tingkat pendidikan yang dimiliki akan berpengaruh terhadap kegiatan penyuluhan yang memerlukan tingkat pengetahuan untuk dapat memahaminya.Menurut Mardikanto (1993), tingkat pendidikan yang dimiliki akan berpengaruh terhadap kegiatan belajar yang memerlukan tingkat pengetahuan untuk dapat memahaminya.Pendidikan non formal merupakan pendidikan yang diperoleh peserta di luar pendidikan formal dan diukur dari frekuensi responden mengikuti kegiatan penyuluhan maupun pelatihan dalam jumlah keikutsertaan pada satu tahun terakhir.Petani peserta kegiatan penyuluhan yang difasilitasi BP3K Kecamatan Teras mendapatkan lebih dari tiga kali pelatihan dalam setahun.

b. Sumber Daya Pendukung

Gratelueschen (1976) dalam Sudjana (2006) memaparkan bahwa aspek-aspek sumber daya pendukung yang dievaluasi adalah keterlibatannya dalam program dan penampilannya dalam proses pembelajaran. Berdasarkan penelitian di lapang, sumber daya pendukung dalam fasilitasi BP3K di Kecamatan Teras sudah cukup terlibat dalam proses perencanaan, pelaksanaan dan evaluasi program. Dukungan penyuluh terhadap program fasilitasi BP3K di kecamatan Teras ialah ikut terlibat aktif dalam setiap kegiatan penyuluhan yang terdapat dalam program fasilitasi BP3K baik itu tahap persiapan, pelaksanaan hingga program selesai dilaksanakan.

Dukungan ketua poktan terhadap program fasilitasi BP3K di Kecamatan Teras ialah ketua poktan ikut terlibat dalam kegiatan penyuluhan. Dukungan lebih lanjut dari ketua poktan sendiri ialah menularkan/ menyebarkan informasi yang didapat dari kegiatan penyuluhan terhadap petani lain yang tidak terdatfar sebagai peserta kegiatan penyuluhan.

\section{c. Fasilitas (Sarana dan Prasarana Program )}

Alat bantu yang disiapkan penyuluh untuk pelaksanaan kegiatan penyuluhan dalam program fasilitasi $\mathrm{BP} 3 \mathrm{~K}$ sudah tergolong efektif. Alat bantu yang disiapkan 
untuk pelaksanaan kegiatan penyuluhan (rembug tani, kursus tani, dan FFD) berupa lembar persiapan penyuluh, mic, sound system, laptop dan proyektor. Alat peraga yang digunakan penyuluh dalam program fasilitasi BP3K sudah efektif untuk membantu penyampaian materi penyuluhan ke petani peserta. Alat peraga yang digunakan berupa slide materi, video tutorial, lembar materi penyuluhan dan sample bahan yang digunakan untuk mendemonstrasikan cara dan praktek langsung di depan peserta. Demonstrasi cara ini dilakukan agar tidak terjadi kesalahan teknis oleh petani peserta dalam menerapakan jajar legowo.

\section{Aspek Process (Proses)}

Keterlibatan petani dalam perencanaan program fasiltasi BP3K ialah petani dijadikan objek / sasaran dari kegiatan, petani diundang untuk menghadiri pertemuan yang diadakan penyuluh di kecamatan untuk menyampaikan masalah-masalah yang dihadapi penyuluh dalam berusaha tani. Peserta kegiatan penyuluhan pertanian dalam progam fasilitasi BP3K merupakan peserta yang aktif dalam mengikuti penyuluhan. Dalam presensi kehadiran peserta selalu terisi penuh dan juga antusias dalam menerima materi penyuluhan yang diberikan serta mau bertanya ketika merasa belum jelas atas penjelasan penyuluh.

Tujuan dari program fasilitasi BP3K di Kecamatan Teras pada tahun 2016 telah tercapai yaitu adanya percepatan peningkatan produksi hasil pertanian setelah diadakannya program fasilitasi BP3K. Petani peserta mau menerapkan jajar legowo yang didapatkan danmau menularkan ilmunya pada petani lain yang tidak menjadi peserta kegiatan penyuluhan. BP3K Kecamatan Teras juga mendapat Juara 1 BP3K terbaik tahun 2016, baik itu dalam tingkat provinsi maupun nasional.

Peninjauan dan pendampingan setelah program selesai dilaksanakan masih kurang. Keterlibatan petani dalam evaluasi program fasilitasi BP3K ialah petani sebagai peserta diberi kesempatan untuk menanggapi pelaksanaan kegiatan penyuluhan kepada penyuluh baik itu berupa kritik, saran, maupun pendapat dari petani itu sendiri yang nantinya akan dicatat dan dijadikan bahan evaluasi oleh penyuluh. Pelaporan kegiatan sepenuhnya dilakukan oleh penyuluh kecamatan, setiap BP3K yang mendapat bantuan fasilitasi diberi form pelaporan kegiatan yang harus dikirimkan setiap tiga bulan sekali melalui Dinas Pertanian Kabupaten Boyolali kemudian diteruskan ke Badan Koordinasi Penyuluh Jawa Tengah.Saran untuk keberlanjutan program fasilitasi BP3K ini ialah penyuluhan dengan teknik seperti ini lebih digiatkan,untuk personil penyuluh di kecamatan ditambah, kemudian setelah program selesai sebaiknya ada pendampingan dan follow up dari penyuluh agar program ini tidak langsung hilang begitu saja.

\section{Aspek Product}

Program fasilitasi BP3K membawa kebermanfaatan ke petani hal tersebut dibuktikan dengan adanya peningkatan produksi hasil pertanian. Program ini juga menambah kecakapan petani dalam menanggapi dan menggunakan inovasi /teknologi pertanian salah satunya membuat petani melakukan eksperimen terhadap pola sistem tanan jajar legowo, petani mau menanam secara serempak dan berdampak juga pada penanganan hama secara serempak yang berarti mengurangi pengeluaran petani secara individu.

Materi yang diberikan dalam program fasilitasi BP3K merupakan materi yang telah disepakati oleh petani dan penyuluh dalam kegiatan rembug tani. Materi tersebut sesuai dengan yang diharapkan oleh petani untuk menghadapi masalah yang terjadi di lapang.Penerapan sistem tanam jajar legowo di Kecamatan Teras pada saat berjalannya program fasilitasi BP3K mencapai $80 \%$ dari keseluruhan petani padi yang ada di kecamatan Teras. Setelah program fasilitasi BP3K selesai dilaksanakan penerapan sistem tanam jajar legowo di kecamatan Teras menurun di bawah $50 \%$ dari keseluruhan petani padi.

Permasalahan petani dalam penerapan sistem tanam jajar legowo ialah sulitnya mencari buruh tanam yang mau menanam padi dengan sistem tanam jajar legowo, kalaupun ada upahkerjanya lebih tinggi dibanding harga buruh tani dengan sisten tanam biasa, tersedianya rice transplanter akan tetapi 
tidak ada nya pertani yang mau dan mahir menjalankan rice transplanter. Selain itu tidak adanya pendampingan lanjutan untuk menanam padi dengan sistem jajar legowo oleh penyuluh membuat petani enggan untuk menanam padi dengan sistem jajar legowo.

\section{Keefektifan Fasilitasi BP3K di Kecamatan Teras}

Pengetahuan petani peserta program fasilitasi BP3K bertambah dengan adanya materi, simulasi, praktek, pengamatan dan anlisis oleh penyuluh. Fasilitas yang diberikan oleh penyelenggara kepada pesertamemadai sehingga peserta dapat mengikuti program dengan fasilitas yang baik Petani peserta program fasilitasi BP3K menyalurkan ilmunya kepada petani lain didalam kelompok tani mereka, sehingga informasi yang ada tidak terputus hanya pada peserta fasilitasi BP3K saja. Dari pihak penyelenggara penyuluhan juga membuatkan grup media sosial untuk para peserta dan fasilitator untuk berbagi informasi meskipun program Fasilitasi BP3K telah selesai.

Tingkat keberlanjutan pasca program fasilitasi BP3K tergolong kurang berlanjut, hal tersebut dikarenakan hanya sedikit petani yang mau menerapkan inovasi pertanian yang diberikan dalam penyuluhan yang difasilitasi BP3K. Pasca program tersebut petani enggan menerapkan inovasi penyuluhan yang diberikan khususnya sistem tanan jajar legowo walaupun meningkatkan provitas dan produktivitas. Hal tersebut dikarenakan tidak adanya pendampingan dan bantuan dari penyuluh di Kecamatan Teras setelah program selessi dilaksanakan.

Program penyuluhan Fasilitasi BP3K di Kecamatan Teras merupakan salah satu program yang tergolong efektif, selain meningkatkan produksi tanaman pangan, program ini juga meningkatkan keterampilan petani dalam menerapkan inovasi baru dalam pertanian. Keefektifan teknik penyuluhan yang digunakan dalam program fasilitasi BP3K sudah baik, terbukti dengan tercapainya tujuan program fasilitasi BP3K yaitu terjadinya percepatan peningkatan provitas dan produktivitas hasil pertanian di kecamatan Teras pada tahun 2016. Selain hal tersebut teknik penyuluhan yang digunakan dalam program fasilitasi BP3K saling berkaitan sehingga kegiatan penyuluhan dibuat secara terstruktur dalam penyampaian kepada peserta.

Kekurangan dari penyelenggaraan program fasilitasi $\mathrm{BP} 3 \mathrm{~K}$ ini adalah kurangnya waktu pelaksanaan.Peserta fasilitasi BP3K merasa waktu hanya dua kali musim tanam itu terlalu singkat.Sehingga ada beberapa lokasi yang merasa hanya mendapatkan pengetahuan tentang jajar legowo saja dan sedikit pendampingan sehingga belum mampu mengaplikasikannya dengan maksimal. Pendampingan pasca program dari pihak keseluruhan yang terkait juga dirasa kurang. Ada lokasi yang memiliki pendampingan yang baik ada pula yang tidak. Semua pihak mulai dari penyuluh setempat dan pemerintah daerah perlu memberikan pendampingan pasca program untuk keberlanjutan program.

\section{KESIMPULAN DAN SARAN}

\section{Kesimpulan}

Berdasarkan hasil penelitian dan pembahasan yang telah dilakukan, maka dapat diperolehkesimpulan sebagai berikut:(1) Pelaksanaan teknik penyuluhan BP3K di Kecamatan Teras Kabupaten Boyolali dilihat dari aspek context tergolong baik dan memadai. Aspek context yang di dalamnya terdapat kondisi sosial ekonomi dan kondisi lingkungan geografis mampu mendukung suksesnya program teknik penyuluhan Fasilitasi BP3K dalam penerapan jajar legowo di Kecamatan Teras.(2)Pelaksanaan teknik penyuluhan BP3K di Kecamatan Teras Kabupaten Boyolali dilihat dari aspek input tergolong baik dan memadai. Aspek input merupakan aspek yang dapat menentukan bagaimana sumber-sumber dapat digunakan untuk mencapai tujuan program. Sumber daya pelaksana, sumber daya pendukung dan fasilitas yang merupakan aspek input dalam fasilitasi BP3K di Kecamatan Teras yang ikut mendukung dan menentukan tercapainya tujuan dari program. (3) Pelaksanaan teknik penyuluhan BP3K di Kecamatan Teras Kabupaten Boyolali dilihat dari aspek process tergolong baik, terdiri dari perencanan program,pelaksanaan program dan pasca pelaksanaan program. Aspek process juga dapat meninjau kembali kesesuaian rencana dengan pelaksanaan program fasilitasi BP3K di Kecamatan Teras. Aspek process sendiri berisi sinergi yang baik antara petani sebagai 
sasaran kegiatan penyuluhan dengan penyuluh sebagai pelaksana kegiatan penyuluhan dalam mencapai tujuan dari program. (4)Pelaksanaan teknik penyuluhan BP3K di Kecamatan Teras Kabupaten Boyolali dilihat dari aspek product tergolong baik dan berhasil. Aspek product digunakan untuk mengukur keberhasilan dan capaian-capaian program. Perubahan jangka pendek diukur dari pengetahuan yang mampu diterima oleh petani peserta sedangkan perubahan jangka panjang diukur dari kemauan peserta dalam menerapkan inovasi pertanian yang telah diberikan yaitu jajar legowo. Petani peserta kegiatan penyuluhan dapat menerima materi penyuluhan yang telah diajarkan dengan baik dan mau menerapkan jajar legowo dalam berusahatani sehingga mampu meningkatkan hasil produksi pertaniannya.(5)Keefektifan teknik penyuluhan yang digunakan dalam program fasilitasi BP3K sudah baik, terbukti dengan tercapainyapercepatan peningkatan provitas dan produktivitas hasil pertanian di Kecamatan Teras pada tahun 2016. Teknik penyuluhan yang digunakan dibuat secara struktur dalam penyampaiannya dan peserta kegiatan penyuluhan yang difasilitasi BP3K merasa puas terhadap kegiatan penyuluhan karena mendapat materi penyuluhan yang sesuai dengan kebutuhan dan mendapatkan tambahan pengetahuan mengenai jajar legowo yang mampu menambah kecakapan petani dalam berusahatani padi sehingga mampu meningkatkan produktivitas pertanian.

\section{Saran}

Berdasarkan hasil penelitian dan uraian kesimpulan pada penelitian ini dapat diajukan saran sebagai berikut: 1)Bagi petani, perlu ditingkatkan keaktifan dalam mengikuti kegiatankegiatan terkait program penyuluhan maupun terkait informasi lainnya di bidang pertanian, melalui sosialisasi, pelatihan, kegiatan lainnya sehingga dapat meningkatkan wawasan dan pengetahuan petani. 2) Bagi penyuluh pertanian lapang Kecamatan Teras, sebaiknya perlu diadakan pendampingan lanjutan oleh penyuluh terkait program fasilitasi BP3K yang di dalamnya terdapat penyuluhan tentang jajar legowo agar petani tetap mau menerapkan materi yang sudah diajarkan dalam penyuluhan. 3) Bagi kelompok tani terkait pemberian bantuan berupa alat mesin pertanian sebaiknya digunakan dan dimanfaatkan untuk kepetingan kelompok sehingga seluruh anggota kelompok tani dapat menerima manfaatnya. 4) Bagi penelitian lain yang sejenis, diharapkan terdapat penelitian lanjutan terkait program fasilitasi BP3K setelah pelaksanaan kegiatan serta evaluasi bagi program tersebut agar menjadi pertimbangan untuk perbaikan program setelahnya .

\section{DAFTAR PUSTAKA}

Departemen Pertanian. 2004. Dasar Dasar Penyuluhan Pertanian. http://www.pustaka. deptan.go.id.

Kementrian Pertanian.2016. Petunjuk Teknis Teknologi Tanam Jajar Legowo. Jakarta: Direktorat Jenderal Tanaman Pangan Kemnetrian Pertanian.

Mardikanto, T. 1993. Penyuluhan Pembangunan Pertanian. Surakarta: UNS Press.

Mardikanto, T. 1997. Penyuluhan Pembangunan Pertanian. Surakarta : Sebelas Maret University Press

Mardikanto, T. 2007. Sistem Penyuluhan Pertanian. Surakarta: UNS Press.

Payman, S. J. 1985. Pengukuran Produktivitas. Jakarta: Ghalia. Indonesia

Peraturan Menteri Pertanian nomor 52/ permentan/T.140/12/2009 tentang Metode Penyuluhan Pertanian.

Pusat Penyuluhan Pertanian Badan Penyuluhan Dan Pengembangan Sdm Pertanian Kementerian Pertanian. Pedoman Pelaksanaan Peningkatan Kapasitas BP3K

Rivai S. R. dan Iwan S. A. 2011. Konsep Dan Implementasi Pembangunan Pertanian Berkelanjutan Di Indonesia. Jurnal Penelitian Forum Agro Ekonomi. 29(1): 13.

Rossi PH dan Howard EF.1993. Evaluation, A Systematic Approach. Sage Publictaion, Inc.

Saebani, Beni A. 2008. Metode Penelitian Hukum. Bandung: Pustaka Setia. 
Sandiani, Ni Kadek. 2014. analisis komparatif pendapatan usahatani padi sawah sistem tanam jajar legowo 2:1 dan 4:1 di desa puntari makmur kecamatan witaponda. e-j. agrotekbis 2 (2) : 199-204

Sastraatmaja, E. 1993.Penyuluhan Pertanian. Bandung: Penerbit Alumni

Setiana. L. 2005. Teknik Penyuluhan dan Pemberdayaan Masyarakat. Bogor.

Setiawan. 2007. Pembangunan Pertanian Berkelanjutan Melalui Kemitraan Usaha. Jurnal Litbang Pertanian. Vol 26(4) :123130

Soeratno, dan Lincolin A.2002. Metodologi Penelitian Untuk Ekonomi dan Bisnis. Yogyakarta.UPP STIM YKPN.

Sudjana, D. 2006. Evaluasi Program Pendidikan Luar Sekolah (Untuk Pendidikan Nonformal dan Pengembangan Sumber Daya Manusia). Bandung : Falah Production.

Surakhmad, Winarno, 2002. Pengantar Penelitian Ilmiah, Dasar, Metode dan Teknik. Bandung : Tarsito.

Van den Ban A.W dan H.S. Hawkins. 2003. Penyuluhan Pertanian. Yogyakarta. Kanisius 